\title{
Production of Compact Powder Blush On using Secang Wood Extract (Caesalpinia sappan L.)
}

\author{
Rety Setyawaty*, Mela Dwiyanti, Dewanto \\ Pharmacy Academy of Kusuma Husada Purwokerto \\ Corresponding author: Rety Setyawaty: Email: rety.setyawaty@gmail.com \\ Submitted: 07-08-2019 \\ Revised: 02-09-2019 \\ Accepted: 18-09-2019
}

\begin{abstract}
Secang wood (Caesalpinia sappan L.) is one of the local resources that contain natural pigments, namely brazilin. Brazilin is a pigment derived from Secang wood (Caesalpinia sappan L.) that is potentially used as a natural dye. This study aims to prove that Secang Wood (Caesalpinia sappan L.) can be applied as a dye from Compact Powder Blush On and see its stability color of product. The method for obtaining Secang wood (Caesalpinia sappan L.) extract uses the maceration extraction method with a sample of Secang wood (Caesalpinia sappan L.) of 250 gram and ethanol $96 \%$ then evaporated in a water bath with a temperature below $80{ }^{\circ} \mathrm{C}$. The thick extract of Secang wood (Caesalpinia sappan L.) is $27.87 \%$. pH during the maceration process must be kept neutral. Addition of citric acid or sodium bicarbonate is done when the $\mathrm{pH}$ unstable. Raw material of manufacture the Compact Powder Blush On is Talcum, Kaolin, Parrafin Liquid, Okside Zinc, and Isopropyl myristate. The Secang wood extract (Caesalpinia sappan L.) concentration is 5\%, 10\%, and $20 \%$. Tests on physical compact powder blush on are pH test, sticky power test, topical test, and stability color of compact powder blush on. The observations show that the Compact Powder Blush On product at a concentration of Secang wood extract (Caesalpinia sappan L.) of 5\%, 10\%, and 20\% is easily applied, has an average adhesion of $13.83 \%$, produces a pink color when application, and has a pH of 7. However, the usage of Secang wood (Caesalpinia sappan L.) as a Blush On dye does not have color stability. Based on the results of the study it can be concluded that Secang Wood (Caesalpinia sappan L.) can be used as a natural dye Compact Powder Blush On, but the addition of other ingredient is needed so that the color remains stable during storage at room temperature.

Keywords: Brazilin; components of the Compact Powder Blush On; natural dye; Secang wood
\end{abstract} (Caesalpinia sappan L.) extract

\section{INTRODUCTION}

The Indonesian state has abundant natural resources to be used and useful for human life, one example of which is benefits from secang wood. Secang wood is a plant that has long been used as a traditional medicine. The components of bioactive compounds contained in secang wood such as brazilin, brazilein, 3'-0-methylbrazilin, sappanone, chalcone, sappancalchone and other common components such as amino acids, carbohydrates and palmitic acids are relatively very small (Rina, 2013).

The presence of the Brazilian component gives specifics from secang wood, which is brownish red if oxidized or in an alkaline atmosphere. However, it is Brazilin which is thought to have the effect of protecting the body from poisoning due to chemical radicals. Secang wood which has colored pigments caused by the presence of brazilin compounds gives coloring from old orange to thick red. In the application of the use of secang wood as traditional medicine in some regions, it is more familiar with secang wood with pink color (Rina, 2013). Based on its antioxidant activity, Brazilin has the effect of protecting the body from chemical radical poisoning (Zhong et al., 2009). Furthermore Rusdi et al. (2005) stated that secang wood extract has the best antioxidant ability compared to vitamin $\mathrm{C}$ and vitamin $\mathrm{E}$, and is able to increase the value of the Total Antioxidant Unit in the body. Flavonoids contained in wood extract have a number of abilities to reduce or inhibit the formation of hydroxyl free radicals, superoxide anions, peroxyl radicals, alkoxyl radicals, singlet oxygen, and hydrogen peroxide (Rahmawati, 2011).

In the field of cosmetic formulations, dyes which are mixed into the manufacture of cosmetics are dyes from chemicals and natural dyes. Dyes are substances or mixtures of substances which can be used in cosmetic preparations to color preparations. 
Table I. Formulation of Compact Powder Blush On

\begin{tabular}{lccc}
\hline \multirow{2}{*}{ Substances } & \multicolumn{3}{c}{ Amount in Percent (\%) } \\
\cline { 2 - 4 } & Formulation 1 & Formulation 2 & Formulation 3 \\
\hline Secang wood extract & $5 \%$ & $10 \%$ & $20 \%$ \\
Talcum & $38 \%$ & $38 \%$ & $38 \%$ \\
Kaolin & $20 \%$ & $20 \%$ & $20 \%$ \\
Paraffin Liquid & $10 \%$ & $10 \%$ & $10 \%$ \\
Zinc Oxide & $22 \%$ & $22 \%$ & $22 \%$ \\
Isopropyl myristate & $10 \%$ & $10 \%$ & $10 \%$ \\
\hline
\end{tabular}

Substances of natural dyes are dyes that come from nature such as animals, minerals and plants both directly (Adliani et al., 2012). The chemical elements contained in beauty products are very dangerous for skin health. The danger posed is very diverse such as zits, black spots and many more skin diseases caused by the chemical content of cosmetics on the market. Based on the results of laboratory investigations and testing by the Indonesian Food and Drug Administration (BPOM RI) in 2007, circulating cosmetics found 27 cosmetic brands containing dangerous ingredients and were prohibited from being used in cosmetics as dyes such as Rhodamin B (red K. 10 and red K. 3) (BPOM RI, 2007). Public health about the dangers of chemical-based cosmetic products makes them tend to choose products derived from natural ingredients that are safer for the skin. Natural ingredients can be natural dyes from natural, natural ingredients or natural dyes for blush on that are safe and have benefits that are in accordance with their use.

Blush on is a cosmetic preparation that is used to color the cheeks with an artistic touch so that it can enhance the fresh impression in makeup. Blush on is used with the aim to correct the face so that the face looks prettier, fresher and more dimensional (Kustanti, et al, 2008). Blush on has several forms including liquid, cream, solid/cake and powder (Astati, 1996). Blush on is available in a variety of colors namely red, orange, pink and brownish (Kustanti, et al, 2008). Blush on is created from attractive colors and of course using dyes. It's just a negative influence on the skin of the face, especially the cheeks, which begins with itching and then flushing and even flaking skin (Rostamailis, 2005). Blush on itself, its function is to provide a tapered accent and more fresh on the face. Highlight the cheekbones, so that they can correct the face so it's not too rounded. On the other hand, those with too thin faces, blush on can also disguise and give volume to the cheeks.

From the explanation that has been explained about Brazilin in secang wood and cosmetics, the researchers are interested in making the extract of secang wood as a natural dye in the formulation of compact powder preparations Blush On.

\section{METHODS \\ Equipments}

Blades, blenders, sieves, porcelain cups, measuring cups, digital scales, pipettes, spoons, stirring rods, funnels, thermometers, filter paper, a set of maceration tools for extraction, universal $\mathrm{pH}$, mortars, pestles, ovens, and places for compact blush products on.

\section{Materials}

The main ingredient is Secang Wood (Caesalpinia sappan L.). Other ingredients: talcum, kaolin, zinc oxide, paraffin liquid, isopropyl myristate and ethanol 96\%. The overall formulation of Compact Powder Blush On from secang wood extract (Caesalpinia sappan L.) can be seen in Table I.

According to Table I, the concentration of Secang wood extract (Caesalpinia sappan L.) is $5 \%$ (F1), 10\% (F2) and 20\% (F3). Other components, such as talcum (38\%), kaolin (20\%), paraffin liquid (10\%), zinc oxide $(22 \%)$, and isopropyl myristate (10\%) is used to make compact powder blush on.

\section{Procedures}

\section{Extraction of brazilin}

The simplicia of secang wood is mashed and then extracted by maceration by dissolving as much as 250 grams of secang wood powder, then adding $96 \%$ ethanol as much as $500 \mathrm{ml}$ or until the simplicia powder is completely 
Table II. Result of $\mathrm{pH}$ test

\begin{tabular}{cccc}
\hline Concentration of extract & Blush On & pH & Average \\
\hline $5 \%$ & Formulasi 1 & 7 & \\
$10 \%$ & Formulasi 2 & 7 & 7 \\
$20 \%$ & Formulasi 3 & 7 & \\
\hline
\end{tabular}

submerged. Simplicia powder must be completely submerged in $96 \%$ ethanol. Then, check the $\mathrm{pH}$ whether it is neutral, if not add a little citric acid or sodium bicarbonate to neutral pH. Every day stirring is carried out, filtering with new cloth and solvent is replaced to obtain the perfect filtrate. After approximately 48 hours in room temperature and avoid sunlight, all the filtrate obtained is concentrated above the waterbath (Putri et al., 2018). Concentration of secang wood extract was carried out at a temperature of $80^{\circ} \mathrm{C}$ (Rina, 2013).

The process of making compact powder blush on First prepare ingredients which include thick extract of secang wood, talcum, kaolin, paraffin liquid, zinc oxide, isopropyl myristate.

Before the formulation is carried out, each additional material is sieved with no. 100 . Second, ingredients other than the thick extract of secang wood and isopropyl myristate are mixed and crushed to a small and soft particle size. After softening, the thick extract of secang wood and isopropyl myristate is added to the mixture of ingredients little by little. Then, compact powder products that have been prepared are placed in containers. Compact powder blush on is tested.

\section{Test the Compact Powder Blush On}

Physical quality testing of preparations compact powder blush on includes $\mathrm{pH}$ test, sticky power test, and stability color of compact powder blush on.

\section{RESULTS AND DISCUSSION Determination}

Plant determination was carried out at the Plant Taxonomy Laboratory of the Faculty of Biology, Jendral Soedirman University, Purwokerto. Based on the results of the determination of the secang wood plant (Caesalpinia sappan L.), it was obtained certainty that the plants that were determined and used for this study were truly tribes of the
Leguminosae family and species of Caesalpinia sappan $L$.

\section{Extraction of brazilin}

The final extraction results with maceration obtained by thick reddish brown extract and distinctive smell. From $1500 \mathrm{ml}$ of liquid extract obtained 69.68 gram thick extract and yield of $27.87 \%$. This is because when evaporating the extract does not get too thick and refers to the research journal about the Formulation of Cheek Blush Preparations from Rossela Petal Extract (Hibiscus sabdariffa Linn.) As dyes in the form of compact powder, the yield is $25.17 \%$ (Bindharawati et al. 2015). On the other hand, research on secang wood by Fardhyanti and Riski (2015) with the title Brazilin collection from Secang Wood (Caesalpinia sappan L) with the maceration method and its application for fabric color mentioned that the viscous extract obtained was $6.316 \%$. The secang wood extract standard itself is not stated in the Indonesian Herbal Pharmacopoeia, therefore it is assumed to be no less than $10 \%(\mathrm{MOH}, 2008)$. Based on several explanations, it can be concluded that the yield obtained in this study still contains a lot of solvents.

\section{Test of Compact Powder Blush On} $p H$ test

Determination of $\mathrm{pH}$ Compact Powder Blush On is using universal $\mathrm{pH}$ paper. Water is added to the preparation until homogeneity later measured $\mathrm{pH}$ of the preparation. $\mathrm{pH}$ measurement done by dipping $\mathrm{pH}$ paper into the homogeneity solution (Ismail et al., 2014). The results of $\mathrm{pH}$ testing can be seen in Table II.

The $\mathrm{pH}$ results from compact powder Blush On in formulations 1,2 , and 3 have a $\mathrm{pH}$ of 7. While the $\mathrm{pH}$ of the extract obtained was 6 . The three $\mathrm{pH}$ formulations are produced in accordance with the $\mathrm{pH}$ for Brazilin, because the color of Brazilin has red color at neutral $\mathrm{pH}$ (6-7), shifts to wards purplish red at higher 
Table III. The results of sticky power test

\begin{tabular}{cccc}
\hline Formulation & Powder weight (g) & Powder falling (g) & Percentage of falling (\%) \\
\hline F1 & 0,1 & 0,0143 & 14,3 \\
F2 & 0,1 & 0,0129 & 12,9 \\
F3 & 0,1 & 0,0117 & 11,7 \\
Average & 0,1 & 0.0130 & 12.97 \\
\hline
\end{tabular}

$\mathrm{pH}(8)$ and yellow at lower pH (2-5) (Adawiyah and Indriati, 2003). However, according to Walters (2002) the $\mathrm{pH}$ requirements of the cheek-blushing preparation that are good in accordance with the skin $\mathrm{pH}$ in general are from 4.0 to 5.5 . On the other hand, Wasitaatmadja (1997) states that $\mathrm{pH}$ of skin in general are 4.57.0. Based on both references, it can be assumed that the $\mathrm{pH}$ produced by compact powder blush on is appropriate.

\section{Sticky Power Test of Compact Powder Blush On}

The sticky power test was conducted to determine how well Blush On is attached to the skin. Weighing $100 \mathrm{mg}$ of blush on, then applied to the surface of the skin with an area of $100 \mathrm{~cm}^{2}$. The location of the skin that is applied is blown with a blower that made of rubber, the powder that falls from the surface of the skin is accommodated in the paper parchment, then weighed powder that falls from the sticky location. Calculate the percentage of falling powder (Voight, 1994).

$$
(\%)=\frac{\text { powder falling }}{\text { powder } \text { weight }} \times 100 \%
$$

The results of sticky power test of the compact powder blush on can be seen in Table III.

The comparison used in this study is a study conducted by Bindharawati, et al. (2015) on the Formulation of Cheek-Blossoming Preparations from Rossela Petal Extract (Hibiscus sabdariffa Linn.) as dyes in the form of compact powder. Bindharawati, et al. (2015) gets the percentage of compact powder blush on that falls is $8.8 \%$. The average percentage of compact powder blush that fell by $12.97 \%$ was greater than that done by Bindharawati, et al (2015). If seen in Table III, all formulas have almost the same falling percentage.

The average percentage of compact powder blush on that fell by $12.97 \%$ was greater than that done by Bindharawati, et al (2015). This means that the compact powder blush on using extract of Secang wood produced only sticks at $87.03 \%$. The use of kaolin on compact powder blush on affects adhesion to the skin. Kaolin is a chemical that is useful for attaching cosmetics to the face, because hygroscopic kaolin is used in cosmetics generally does not exceed 25\% (Nurhayati, 2016). In this study only $20 \%$ of kaolin was used.

\section{Stability Color of Compact Powder Blush On Products}

According to theory, stability is defined as the ability of a medicinal or cosmetic product to stay within the specifications set throughout the period of storage and use to guarantee the identity, strength, quality and purity of the product. A stable cosmetic preparation is a preparation that is still within acceptable limits during the period of storage and use, where the properties and characteristics are the same as those they have when made. This stability test is carried out by observing the physical changes of cosmetics made (Djajadisastra, 2004).

In formulations 1, 2 and 3 there are color changes from pink to brownish red after 5 days of storage in room temperature. This is because the oxidation of hydroxyl groups from Brazilin into carbonyl groups due to exposure to air and light can cause Brazilin to change color to brownish red (Farhana et al., 2015). The results of the compact powder blush on stability test can be seen in Figure 1.

\section{CONCLUSION}

Based on the results of research and discussion, it can be concluded that secang wood (Caesalpinia sappan L.) can be used as a dye in the manufacture of Compact Powder Blush On preparations but other ingredients must be added that can keep the color stable during storage. The physical test of the compact powder blush preparation carried out resulted as follows: In formulations 1,2 , and 3 with the addition of $5 \%, 10 \%$, and $20 \%$ extracts of secang wood (Caesalpinia sappan L.) to produce pink. 


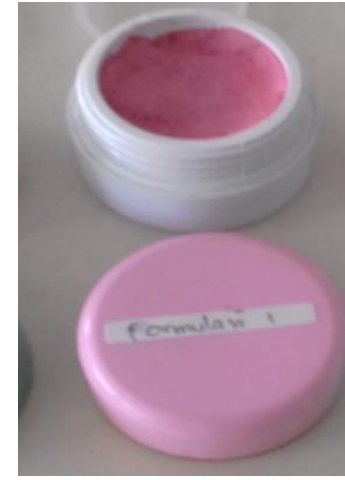

F1 (when the product is finished = day 0)

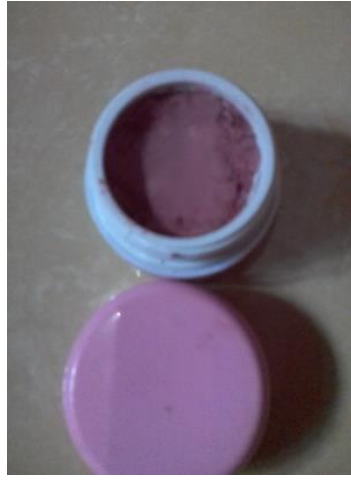

F1 (after the product is stored for 5 days)

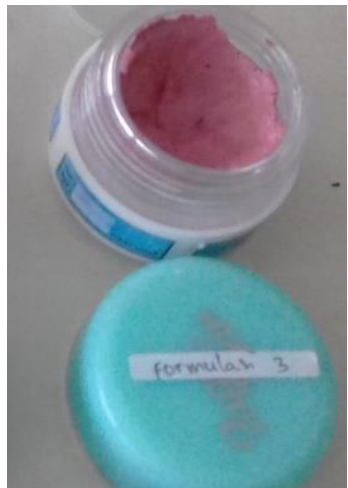

F3 (when the product is finished $=$ day 0 )

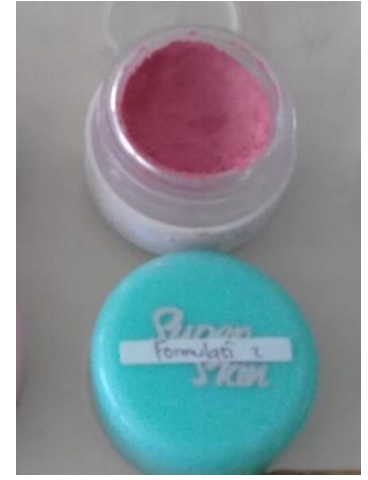

F2 (when the product is finished $=$ day 0 )

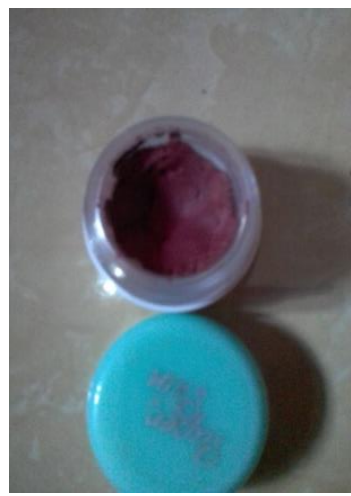

F3 (after the product is stored for 5 days)

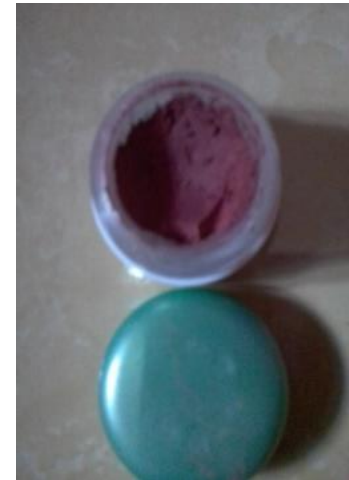

F2 (after the product is stored for 5 days)

Figure 1 . The results of stability color of the compact powder blush on

The $\mathrm{pH}$ test in formulations 1,2 , and 3 has a $\mathrm{pH}$ of 7 in accordance with the $\mathrm{pH}$ of the skin in general, and is in accordance with the $\mathrm{pH}$ of Brazil's stability to produce a pink color. In the sticky power test, all formulas have almost the same falling percentage. In the stability test, after storage for 5 days in room temperature (blush) the color changes from pink to brownish red because the oxidation of the hydroxyl group from Brazilin into carbonyl groups due to exposure to air and light which can cause Brazilin to change color to brownish red.

\section{REFERENCES}

Adawiyah, D. R. and Indriati. 2003. Color stability of natural pigmen from secang wood (Caesalpinia sappan L.). Proceeding of thr $8^{\text {th }}$ ASEAN Food Conference, Hanoi, 8-11 October.

Adliani, N., Nazliniwaty, and Djendaki Purba. 2012. Formulasi Lipstik menggunakan
Zat Warna dari Ekstrak Bunga Kecombrang (Etlingera elatior (Jack) R.M.Sm.). Journal of Pharmaceutical and Pharmacology, Vol. 1 (2), pp. 87-94.

Anonim. 2004. Informasi temulawak Indonesia. Badan Pengawas Obat dan Makanan RI bekerja sama dengan Gabungan Pengusaha Jamu Indonesia.

Astati, Sutriari. 1996. Rias Wajah Sehari - hari. Direktorat Pendidikan Dasar dan Menengah. Jakarta.

Badan Pengawasan Obat dan Makanan RI (BPOM RI). 2007. Kosmetik mengandung bahan berbahaya dan zat warna yang berbahaya. PT. Gramedika Pustaka Utama. Jakarta.

Bindharawati, N., Darsono, F. L., and Sumi Wijaya. 2015. Formulasi Sediaan Pemerah Pipi dari Ekstrak Kelopak Bunga Rosella (Hibiscus sabdariffa Linn.) sebagai Pewarna dalam Bentuk Compact Powder. Journal of Pharmaceutical Science and 
Pharmacy Practice. Vol. 2, No. 2, pp. 3336.

Djajadisastra, J. 2004. Cosmetic Stability.Departemen Farmasi Fakultas Matematika dan Ilmu Pengetahuan Alam Universitas Indonesia.Seminar Setengah Hari HIKI. Jakarta.

Fardhyanti, D. S and Riski, R. D. 2015. Pemungutan brazilin dari Kayu Secang (Caesalpinia sappan L.) dengan metode maserasi dan aplikasinya untuk pewarnaan kain (Brazilin collection from Secang Wood (Caesalpinia sappan L) with maceration method and its application for fabric color). Jurnal Bahan Alam Terbarukan, Vol. 4, No. 1.

Farhana, H., Maulana, I. T., and Reza Abdul Kodir. 2015. Perbandingan Pengaruh Suhu dan Waktu Perebusan terhadap Kandungan Brazilin pada Kayu Secang (Caesalpinia Sappan Linn.). Prosiding Penelitian SPeSIA Unisba, pp. 19-25. ISSN: 24606472.

Ismail, I., Ningsi, S., Tahar, N., and Aswandi. 2014. JF FIK UINAM, Vol. 2, No. 2, pp: 8086.

Kustanti, dkk. 2008. Tata Kecantikan Kulit. Direktorat Pembinaan Sekolah Menengah Kejuruan, Direktorat Jenderal Manajemen Pendidikan Dasar dan Menengah, Departemen Pendidikan Nasional. Jakarta.

$\mathrm{MOH}$ (Ministry of Health). 2008. Farmakope Herbal Indonesia (Indonesian Herbal Pharmacopoeia). Ministry of Health Republic of Indonesia. Jakarta

Nurhabibah, Najihudin A., and Damar Suci Indriawati. 2018. Formulation and Evaluation of Blush On Preparations from The Ethanol Extract of Cinnamon (Cinnamomum burmanni Nees ex BI). Jurnal Ilmiah Farmako Bahari. Vol. 9, No. 2, pp. 33-44. ISSN: 2087-0337.
Nurhayati, Ifa. 2016. Pembuatan Blush On dari Buah Naga. Fakultas Teknik. Universitas Negeri Semarang. Semarang.

Putri, U. S., Mukharomah, A. H., and Ayu R. S. 2018. The Effect of Ethanol Solution Concentration on Brazilin Absorbansibility of Secang Wood Simplicy (Caesalpinia sappan L.). Prosiding Seminar Nasional Mahasiswa Unimus, Vol. 1: 283-288. e-ISSN: 2654-766X

Rahmawati, F. 2011. Kajian potensi 'wedang uwuh' sebagai minuman fungsional. Seminar Nasional 'Wonderfull Indonesia', Jurusan PTBB FT UNY, 3 Desember 2011.

Rina, Oktaf. 2013. Identifikasi Senyawa Aktif dalam Ekstrak Etanol Kayu Secang (Caesalpinia sappan L.). Prosiding Semirata FMIPA Universitas Lampung.

Rusdi, U. D., Widowati, W., and E.T. Marlina. 2005. Efek Ekstrak Kayu Secang, Vitamin E dan Vitamin C terhadap Status Antioksidan Total (SAT) pada Mencit yang terpapar Aflatoksin. Media Kedokteran Hewan, Vol. 21, No. 2, pp. 6668.

Rostamailis. 2005. Penggunaan Kosmetik, Dasar Kecantikan dan Berbusana yang serasi. PT Rineka Cipta. Jakarta.

Voight, R, 1994, Buku Pelajaran Teknologi Farmasi. (Edisi ke 5), Penerjemah Soendani Noerono, Gadjah Mada University, Yokyakarta.

Walters, K. A. 2002. Dermatological and Transdermal Formulation. New York. Marcel Dekker Inc.

Wasitaatmadja, S.M.1997. Penuntun Ilmu Kosmetik Medik. Penerbit Universitas Indonesia (UI-Press). Jakarta.

Zhong, X., Wu, B., pan, Y. J., and Zheng, S. 2009. Brazilein inhibits survivin protein and mrna expression and induces apoptosis in hepatocellular carcinoma HepG2 cells. Neoplasma, 56 (5): 87 - 92. 